\title{
Caryotricha minuta (Xu et al., 2008) nov. comb., a unique marine ciliate (Protista, Ciliophora, Spirotrichea), with phylogenetic analysis of the ambiguous genus Caryotricha inferred from the small-subunit rRNA gene sequence
}

\author{
Miao Miao, ${ }^{1}$ Chen Shao, ${ }^{1}$ Jiamei Jiang, ${ }^{1}$ Liqiong Li, ${ }^{1}$ Thorsten Stoeck ${ }^{2}$ \\ and Weibo Song ${ }^{1}$ \\ ${ }^{1}$ Laboratory of Protozoology, Ocean University of China, Qingdao 266003, PR China \\ ${ }^{2}$ Department of Ecology, University of Kaiserslautern, D-67663 Kaiserslautern, Germany
}

Correspondence

Weibo Song

wsong@ouc.edu.cn

\section{INTRODUCTION}

The taxonomy of the spirotrichs, as a distinct and highly divergent ciliate assemblage, has been subjected to numerous revisions, resulting in contradictory classification schemes (Small \& Lynn, 1981; Carey, 1992; Lynn, 1996; Song \& Wilbert, 1997). In ciliates, the systematic arrangements of some less-common organisms are often ambiguous because of a lack of ontogenetic and molecular data or different views regarding the significance of the presence/absence of some 'key' morphological structures

Abbreviations: BI, Bayesian inference; LS, least squares; MP, maximum parsimony; NJ, neighbour joining; PP, posterior probability; SSU, small subunit; TC, transverse cirrus.

The GenBank/EMBL/DDBJ accession number for the SSU rRNA gene sequence of Caryotricha minuta is EU275202.
(Corliss, 1979; Small \& Lynn, 1985; De Puytorac et al., 1994; Shin et al., 2000; Lynn \& Small, 2002). For instance, the traditional heterotrichs were considered for a long time to be a monophyletic group among the spirotrichs (Kahl, 1932; Corliss, 1979). According to ultrastructural features and molecular information inferred from some marker genes, the aerobic heterotrichs were nevertheless grouped with the primitive karyorelicteans as a sister group (subclass Postciliodesmatophora) of all other ciliates (Gerassimova \& Seravin, 1976; Hammerschmidt et al., 1996; Lynn \& Small, 2002). Moreover, some well-known heterotrichs, e.g. Licnophora and Protocruzia, diverged invariably basal to other typical heterotrichs according to molecular phylogenetic analysis, which indicates that these two groups must be separated from the latter (Lynn \& Strüder-Kypke, 2002). Such examples demonstrate that combined multidiscipli- 
nary approaches are urgently needed to evaluate the systematic relationships of uncertain taxa.

The poorly known genus Caryotricha, belonging to the family Kiitrichidae, represents a unique taxon considering its general morphology. This genus has an ancestral pattern of simple ciliated dikinetids for the dorsal ciliature and uniform cirri on the ventral side, with no differentiation of real marginal rows. For a long time, it has been questioned whether Caryotricha is related to euplotids or to other typical hypotrichs (Corliss, 1979; Small \& Lynn, 1985; Tuffrau \& Fleury, 1994; Shi et al., 1999; Lynn \& Small, 2002). In an accompanying paper, based on ontogenesis and molecular investigations, Kiitricha marina, another kiitrichid, is confirmed to be an intermediate form between heterotrichs and spirotrichs, which suggests that kiitrichids represent a new subclass Protohypotrichia within Spirotrichea (Li et al., 2009).

An isolate was collected and identified as a population of a novel species, Kiitricha minuta, by Xu et al. (2008). Here, we complete the description of the morphology and infraciliature of the novel taxon, analyse its small-subunit (SSU) rRNA gene sequence phylogenetically and reevaluate the Protohypotrichia hypothesis.

\section{METHODS}

Sample collection, observation and identification. Ciliates were isolated on 30 May 2007 from Jiaozhou Bay, Qingdao, China $\left(36^{\circ} 08^{\prime} \mathrm{N}\right.$ $120^{\circ} 43^{\prime} \mathrm{E}$ ), from a water sample with temperature $18{ }^{\circ} \mathrm{C}, \mathrm{pH} \sim 8.0$ and salinity $\sim 31 \%$. Microscopy observations, impregnation and terminology are according to Wilbert (1975) and Song \& Wilbert (1997).

DNA extraction, PCR amplification and sequencing. Individual cells were transferred to lysis buffer solution according to the protocol of Chen \& Song (2001), and PCR was performed as described by Miao et al. (2007). Primers for SSU rRNA gene amplification for ciliates were EukA and EukB, covering nearly the complete gene (Medlin et al., 1988). The purified PCR product of the expected size $(\sim 1.8 \mathrm{~kb})$ was cloned into the pUCm-T vector (Sangon). Plasmid DNA was purified with a plasmid mini-prep spin column kit (Sangon). Sequencing reactions were performed bidirectionally using an ABI Prism 377 automated DNA sequencer (Applied Biosystems) As sequencing primers, we used three internal universal $18 \mathrm{~S}$ primers (forward and reverse) as described by Elwood et al. (1985) together with primers M13F and M13R.

Phylogenetic analyses inferred from sequences of SSU rRNA gene. Sequences for all other ciliates used in this analysis were from the group of the corresponding author and the GenBank/EMBL database. Sequences were aligned with CLUSTAL W version 1.83 (Thompson et al., 1994) and the alignment was refined manually. Primer sequences were removed from the alignment prior to phylogenetic analyses using BioEdit (Hall, 1999). The final alignment comprised 68 taxa and 1862 nucleotide positions. A Bayesian inference (BI) approach as implemented in MrBayes version 3.1.2 (Huelsenbeck et al., 2001) was used to infer phylogenetic relationships. Markov chain Monte Carlo simulations were run for 1000000 generations, with two runs and each run with four simultaneous chains, using a sample frequency of 100 and a burn-in of 2500 trees. The computer program MRMODELTEST (Nylander, 2004) was used to identify the best evolutionary model; the model GTR $+\Gamma_{4}$ was set for among-site rate variation, and allowed all substitution rates of aligned sequence to be different. A maximum-parsimony (MP) tree was calculated by a heuristic search with all characters coded as unordered in PAUP* version $4.0 \mathrm{~b} 10$ (Swofford, 2002); 876 characters were phylogenetically informative and used to find the most parsimonious tree using the heuristic search option. The PHYLIP package version 3.66 (Felsenstein, 2006) was used to calculate sequence similarity and evolutionary distances between pairs of nucleotide sequences using Kimura's two-parameter model (Kimura, 1980). Distance-matrix trees were then constructed using the least-squares (LS) method (Fitch \& Margoliash, 1967) and the neighbour-joining (NJ) method (Saitou \& Nei, 1987). Distance-matrix trees were constructed following Miao et al. (2007). Parsimony and distance data were bootstrap-resampled 1000 times. Four karyorelictean species were selected as an outgroup in the analyses.

\section{RESULTS}

The monotypic genus Caryotricha was established by Kahl (1932) based mainly on living observations of the type species Caryotricha convexa Kahl, 1932. Thereafter, the genus was diagnosed very briefly by Small \& Lynn (1985) and then by Tuffrau \& Fleury (1994). Combined with previous descriptions and the present work, we supply here an improved definition.

\section{Improved diagnosis for the genus Caryotricha}

Marine Kiitrichidae with prominent buccal field; two highly developed undulating membranes; non-grouped cirral rows with uniform cirri on both ventral and dorsal sides; enlarged transverse cirri (TC) irregularly arranged in two short rows; marginal cirri not present; one migratory row located posterior to buccal field; structure of dorsal kineties generally in Kiitricha pattern.

\section{Caryotricha minuta (Xu et al., 2008) nov. comb.}

Basonym: Kiitricha minuta Xu et al., 2008.

Since this organism was somewhat questionably interpreted/defined in original descriptions, we give an improved diagnosis based on both the original report and our present investigations.

\section{Improved diagnosis}

About $70 \times 55 \mu \mathrm{m}$ in vivo; spindle-like cortical granules densely arranged, distributed in irregular rows; adoral zone with about 25 membranelles; about 11 cirral rows on both ventral and dorsal sides which terminate at about the equatorial level of the cell; three to eight slightly differentiated TC arranged in two rows; six to nine migratory cirri positioned posterior to cytostome; seven to nine dorsal kineties and one oval macronuclear nodule.

\section{Deposit of voucher material}

Two voucher slides with protargol-impregnated specimens have been deposited in the Laboratory of Protozoology, 
Ocean University of China (number JJ-20070530-02), and in the Natural History Museum, London, UK (registration number $2007: 9: 1: 1$ ).

\section{Morphological description of the Qingdao population}

Size in vivo about $60-75 \times 50-60 \mu \mathrm{m}$. Body inflexible and form consistent, mostly oval with widely narrowed anterior and posterior ends, some specimens slightly asymmetrical with both cell ends pointed (Figs 1a and 2a, d-f); dorsoventrally flattened about $2: 3$ (Fig. 1d). Buccal field dominant, extending almost $80 \%$ of the cell length (Figs 1a and 2a). Cytoplasm usually full of dark-grey to black inclusions (tiny globules or droplets, usually $2-5 \mu \mathrm{m}$ ) that render the cell completely opaque at low magnification (Fig. 2a). Pellicle rigid, spindle-like cortical 'granules' barshaped, approx. $1 \mu \mathrm{m}$ in diameter and $5 \mu \mathrm{m}$ long, vertically arranged beneath the pellicle (Fig. 1b; arrows), which are distributed in irregular rows along cirral rows (Figs 1e and $2 \mathrm{j}$ ) and densely packed throughout the whole cilium-free area (Figs $1 \mathrm{c}$ and 2c). Food vacuoles containing diatoms and algae (Fig. 2e). Buccal cavity dominant; about eight warts on margin of buccal lip, on which the cirri are located (Figs 1a, e and 2j; arrows). Macronucleus globular or oval in shape, about $25 \mu \mathrm{m}$ in diameter (Figs $1 \mathrm{a}$ and $2 \mathrm{~g}$, l; Ma). Micronuclei not detected.

Since no pulsation was observed, the presence of the contractile vacuole is not clearly confirmable. Yet, one vacuole was recognized in a rather consistent position in some specimens, which is about $10 \mu \mathrm{m}$ in diameter and positioned subcaudally near the right border (Fig. 1a, d).

Locomotion generally inactive, always slowly crawling on substrate; when disturbed, cells swim fast in a straight line while rotating about the main body axis.

Adoral zone slightly curved, extending to about $4 / 5$ of body length, consisting of about 25 membranelles (Fig. 1f; AZM). Undulating membranes about equally long and lying parallel; endoral membrane possibly single-rowed, while paroral membrane multiple in structure, consisting of obliquely arranged rows of kinetosomes (Fig. 1f).

Somatic ciliature is shown in Figs $1(\mathrm{f}, \mathrm{g})$ and $2(\mathrm{k})$. On both the ventral and dorsal sides, cirri are arranged in about 11 longitudinal rows which extend to about the equator of the cell. Cirri generally uniform in shape and non-grouped with exception of TC, which are arranged in two short rows and located at the posterior ends of the second and third inner rows (Fig. 2k, arrows). Bases of TC conspicuously

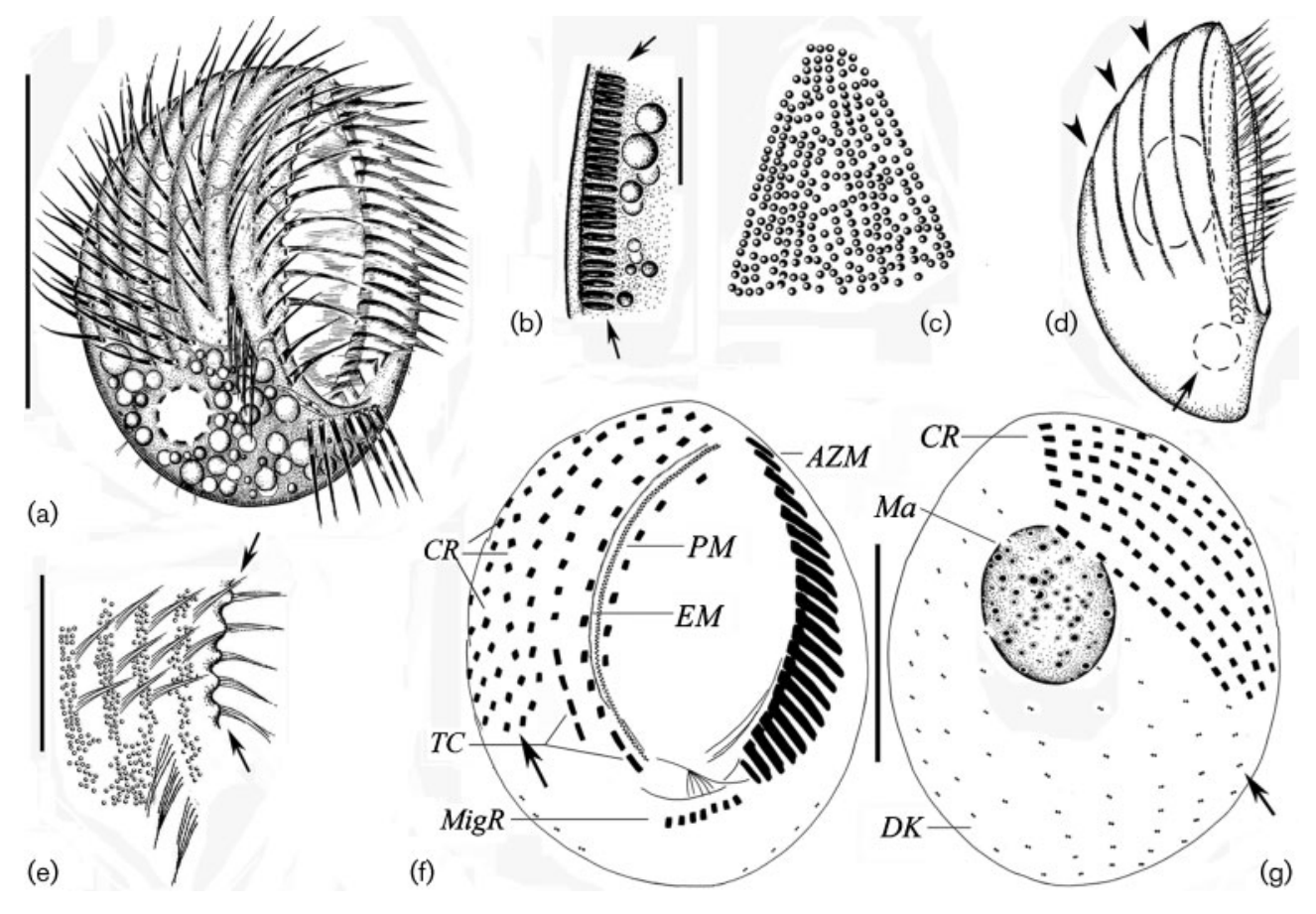

Fig. 1. Morphology and infraciliature of Caryotricha minuta (Xu et al., 2008) nov. comb. from life (a-e) and after protargol impregnation (f, g). (a) Ventral view of a typical individual. (b) Lateral view of cortical granules (arrows). (c) Dorsal view, to show cortical granules. (d) View of the right side; arrowheads mark the spiralized cirral rows and arrow shows the contractile vacuole. (e) Ventral view, to show the cortical granules. Note the warts on the buccal lip (arrows). ( $f, g$ ) Ventral ( $f$ ) and dorsal ( $g$ ) views; an arrow in ( $f$ ) shows the shortened cirral row and an arrow in $(g)$ indicates the dorsal kineties. AZM, Adoral zone of membranelles; $\mathrm{CR}$, cirral rows; DK, dorsal kineties; EM, endoral membrane; Ma, macronucleus; MigR, migratory row; PM, paroral membrane; TC, transverse cirri. Bars, $50 \mu \mathrm{m}(\mathrm{a}), 15 \mu \mathrm{m}$ (b) and $25 \mu \mathrm{m}(\mathrm{e}-\mathrm{g})$. 

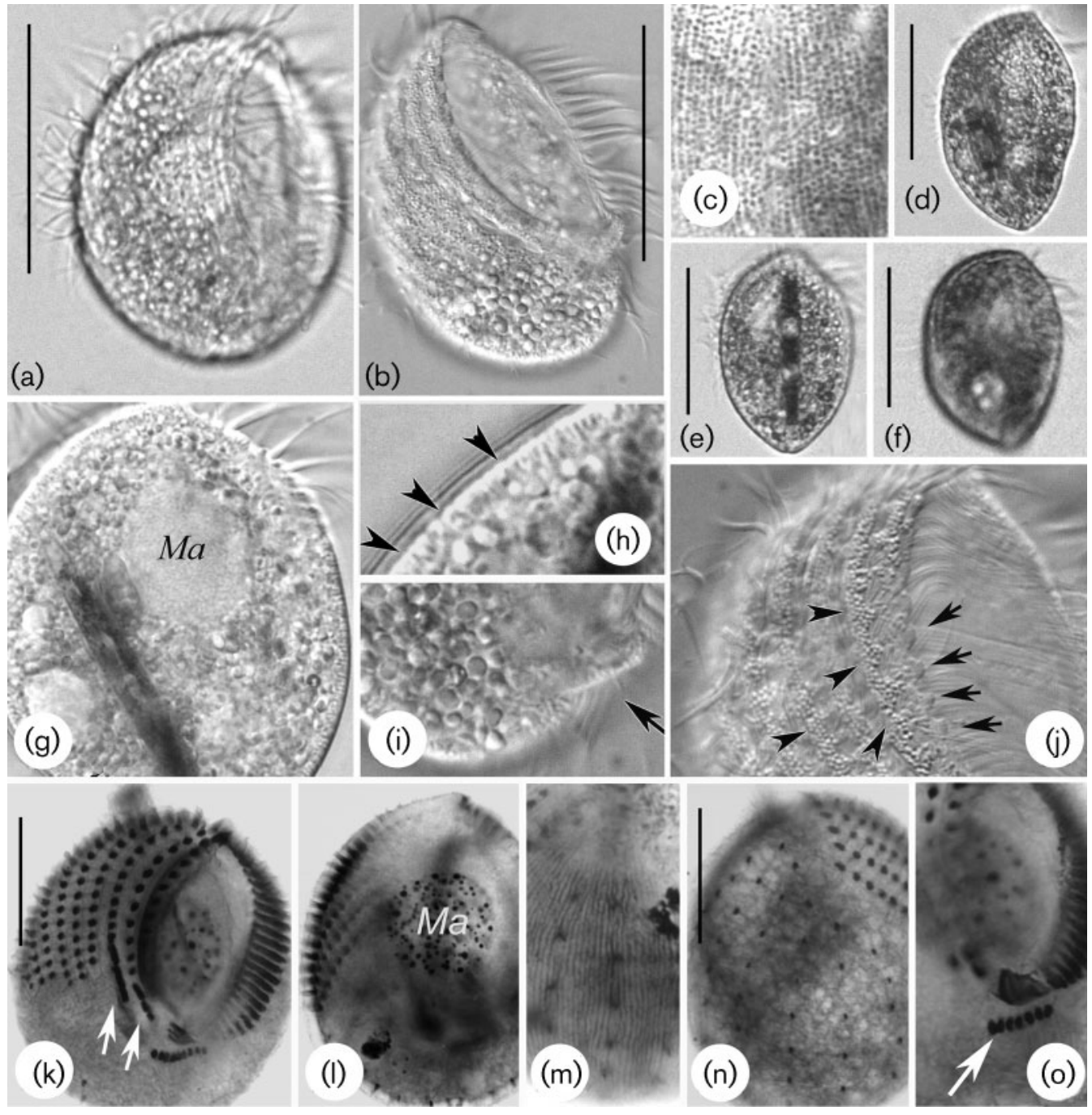

Fig. 2. Photomicrographs of $C$. minuta from life $(a-j)$ and after protargol impregnation $(k-o)$. (a) Ventral view of a typical individual. (b) Ventral view, to show the cytoplasmic inclusions. (c) Dorsal view, to show the cortical granules. (d-f) Ventral views, to show different body shapes. (g) Ventral view, to show the macronucleus and the food vacuoles containing algae. (h) Brim of a depressed cell, to show the lateral view of the cortical granules (arrowheads). (i) Detail showing the migratory row (arrow). (j) Ventral view of the anterior portion, to show the cortical granules (arrowheads) and warts (arrows). (k, l) Ventral (k) and dorsal $(I)$ views, to show the general infraciliature. $(m, n)$ Dorsal views, to show the impregnated cortical granules $(m)$ and the general infraciliature (n). (o) Ventral view; arrow marks the migratory row. Bars, $50 \mu \mathrm{m}(\mathrm{a}, \mathrm{b}, \mathrm{d}-\mathrm{f})$ and $30 \mu \mathrm{m}(\mathrm{k}, \mathrm{n})$.

longer than other cirri and mostly clearly recognizable (Fig. 1f). Posterior to buccal field, one short migratory row (MigR; for terminology, see Discussion) isolated from other ciliature with about six to eight close-set cirri (Figs if and 20 , arrow).

On the dorsal side, seven or eight dorsal kineties as complete rows located on left half of body, both basal bodies of each dikinetids bearing one short cilium, thus in typical mode of Kiitricha pattern. Among kineties, the rightmost one is short and continues anteriorly with the leftmost cirral row, thus making a mixed structure (arrow, Fig. 1g; DK).

\section{Sequence alignment and phylogenetic analysis}

The complete SSU rRNA gene sequence was determined for C. minuta (1744 nt). The $\mathrm{G}+\mathrm{C}$ content $(42.9 \mathrm{~mol} \%)$ is in the same range as reported for most other ciliates (Bernhard et al., 1995). The sequence similarity between C. minuta and the related K. marina is only $87 \%$. The SSU rRNA gene does not contain any conspicuous insertions or deletions.

Analyses (BI, LS, NJ) and the constructed trees gave similar topologies (Fig. 3). The two major ciliate clades, designated the subphyla Postciliodesmatophora (Karyorelictea, Heterotrichea) and Intramacronucleata, are resolved in this analysis. In all three analyses (BI, LS, NJ), differences 


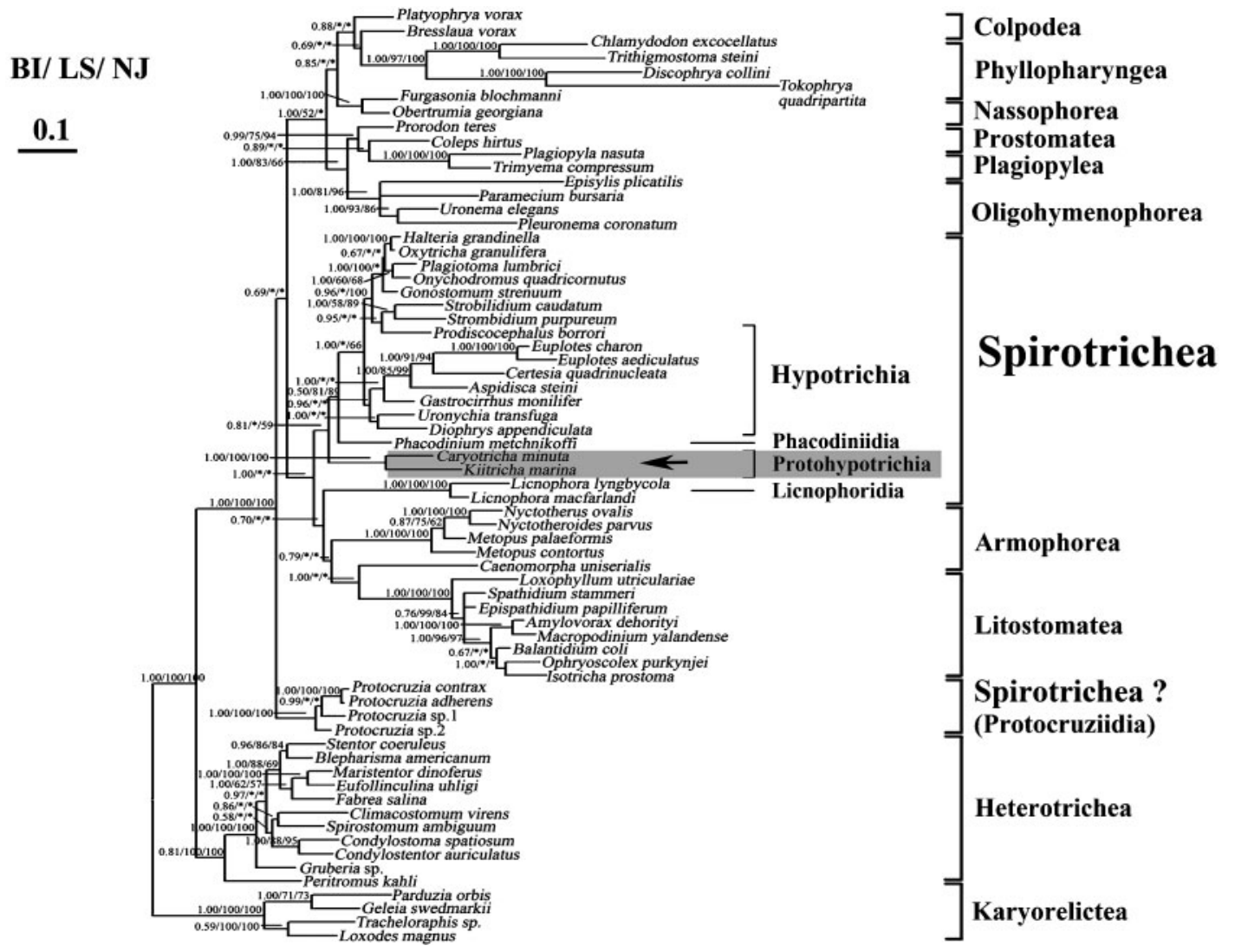

Fig. 3. Bayesian tree inferred from complete nucleotide sequences of the SSU rRNA gene of ciliated protozoa. Numbers at nodes represent support values in the following order: Bayesian PP using the MrBayes algorithm/LS bootstrap values (percentages of 1000 replicates)/NJ bootstrap values (percentages of 1000 replicates). Asterisks indicate bootstrap values less than $50 \%$ and disagreement between a method and the reference Bayesian tree at a given node. Evolutionary distance is represented by branch lengths separating the species. Bar, 10 substitutions per 100 nucleotide positions.

between the trees occurred mainly in the groupings of the ciliate classes within the subphylum Intramacronucleata (i.e. Colpodea, Nassophorea, Prostomatea and Plagiopylea). However, the bootstrap support for the relationships among classes is generally moderate to low. The armophorids and clevelandellids, long considered to be heterotrichs, do not group with the Postciliodesmatophora, but form a sister clade to the litostomes [posterior probability (PP) 0.79].

All phylogenetic trees are congruent regarding the branching pattern within the class Spirotrichea, which indicates that the spirotrichs are invariably paraphyletic. The former heterotrich Licnophora, which had been assigned to the class Spirotrichea (Lynn \& Small, 2002), was associated with the class Armophorea, but always separated from the spirotrichs, though the bootstrap support is low (Fig. 4). The spirotrich clade including the subclasses Oligotrichia, Choreotrichia, Stichotrichia, Hypotrichia and Phacodiniidia and the family Kiitrichidae was demonstrated to be monophyletic with moderate support.

Additional MP analyses were performed (Fig. 4). The major aspects of the topology are similar to those of the distance-matrix trees (compare Fig. 3): Phacodinium is consistently associated with the stichotrich-hypotrichchoreotrich-oligotrich clade and the basal branching of Kiitrichidae and Licnophora from the typical spirotrichs is confirmed. Caryotricha and Kiitricha are related to each other and invariably form a monophyletic clade. This relationship received strong support in all analyses (0.99 PP, $100 \%$ LS, $100 \%$ NJ, $100 \%$ MP).

\section{DISCUSSION}

\section{Identification of the Qingdao population and some ambiguities to be addressed}

Our isolate corresponds perfectly to the Korean population (Xu et al., 2008) regarding the habitat, general morphology, infraciliature and all morphometric features (Table 1; lower lines). Hence, the identification is unquestionable. $\mathrm{Xu}$ et al. (2008) described this organism as a novel species of Kiitricha ( $K$. minuta). Considering the definition suggested by Song \& Wilbert (1997), however, the genus Kiitricha is diagnosed by the lack of the migratory row 


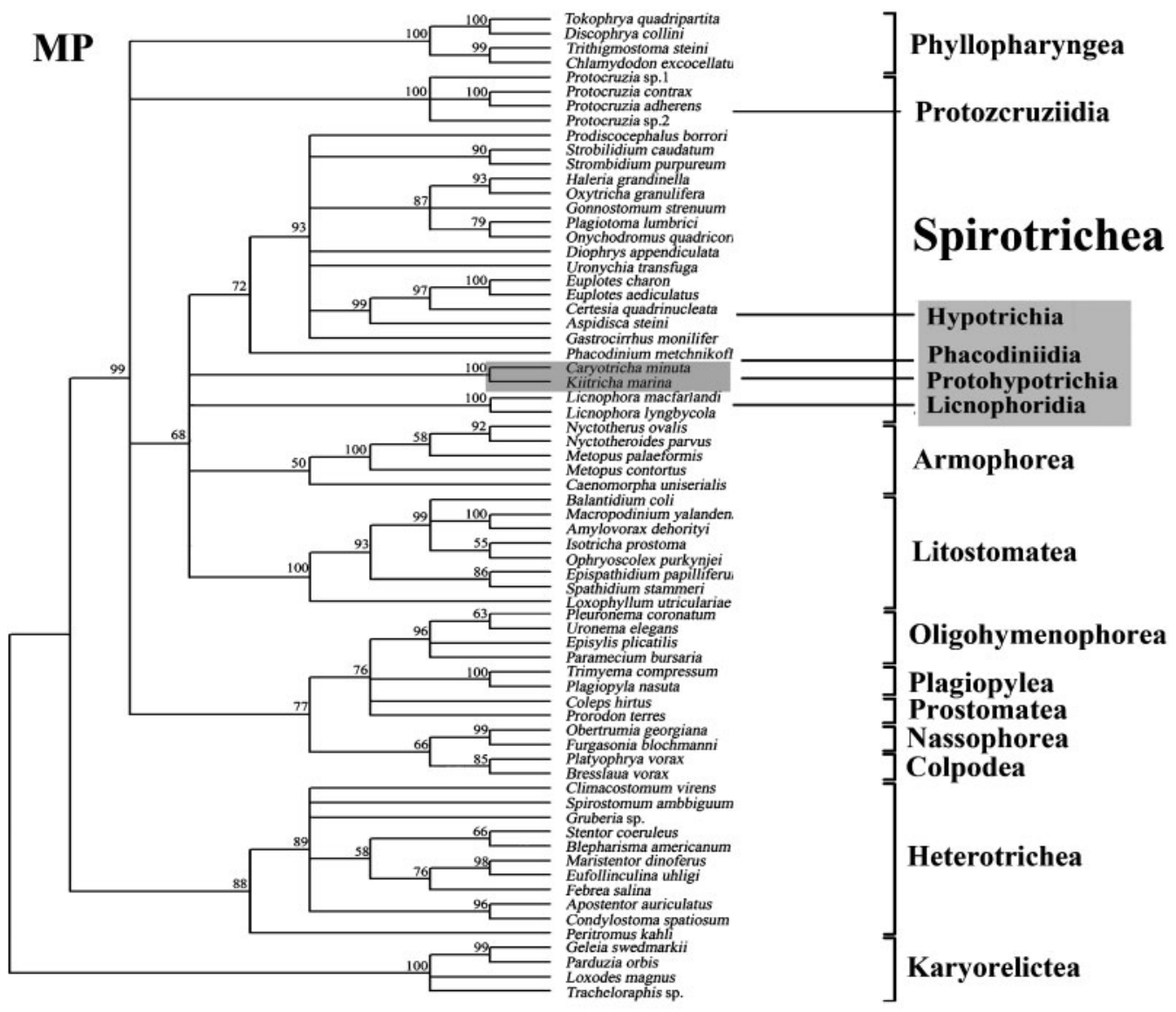

Fig. 4. MP tree of the ciliates constructed from complete SSU rRNA gene sequences. Numbers at nodes indicate percentages of occurrence of a specific branch in 1000 resamplings. No significance is placed on branch lengths connecting the species.

(present in Caryotricha) but having clearly differentiated TC which are arranged in a complete row (variable in number and size and positioned in two rows in Caryotricha, thus lower in differentiation considering their development). In addition, the dorsal ciliature is mixed with normal cirral rows in Kiitricha; that is, some kineties consist of normal cirri and dikinetids with both kinetosomes ciliated. For these reasons, the separation of the two genera is rather distinct and the morphotype K. minuta should be, in our opinion, a member of Caryotricha; thus, a new combination is suggested, Caryotricha minuta nov. comb.

Two further points need to be mentioned. One is the presence of the contractile vacuole: according to $\mathrm{Xu}$ et al. (2008), the contractile vacuole is positioned to the left of the buccal field. However, a re-evaluation (personal communication) indicates that this is possibly a misinterpretation, since no pulsation had been observed in hyaline, vacuole-like areas detected in some cells. Hence the question of whether the contractile vacuole indeed exists remains unsolved. Another arguable matter is the situation of the cortical granules: this feature is also probably incorrectly described in the original report (Xu et al., 2008). The original record/documents do not support their illustra- tions, in which the cortex consists of two kinds of organelles: densely arranged ellipsoid cortical granules and long, barshaped extrusomes which are small in number. Instead, the structure should be uniform, densely spaced and barshaped, as depicted in Fig. 1(b, c) of the current work.

In the present paper, we use the term migratory row instead of submarginal row to refer to the cirral row posterior to the cytostome. The reason is that, as revealed in the closely related K. marina (C. Shao, W. Song, A. Warren, K. A. Al-Rasheid, X. Hu and H. Ma, unpublished), this row derives from the migration of the posterior end of one of frontoventral rows, yet no marginal ciliature was involved or formed (see below).

\section{Comparison with related morphotypes}

Considering the general morphology, the only known congener, C. convexa Kahl, 1932 (Fig. 5d, f), seems very similar to C. minuta. It differs from the latter, however, in the conspicuously long cirral rows which extend to the posterior end of the cell (posteriorly strongly shortened, invariably terminating about half way along the cell in $C$. minuta). 
Table 1. Morphometric data for Caryotricha minuta (Xu et al., 2008) nov. comb.

For each character, the upper value (bold) is for the Qingdao population and the lower value is for the Korean population (Xu et al., 2008). All data are based on protargol-impregnated specimens. Means are arithmetic means. CV, Coefficient of variation (\%); TC, transverse cirri.

\begin{tabular}{|c|c|c|c|c|c|c|}
\hline Character & Min. & Max. & Mean & SD & $\mathrm{CV}$ & $n$ \\
\hline \multirow[t]{2}{*}{ Body length $(\mu \mathrm{m})$} & 45 & 75 & 56.4 & 8.1 & 14.4 & 25 \\
\hline & 36 & 65 & 49.5 & 7.3 & 14.8 & 16 \\
\hline \multirow[t]{2}{*}{ Body width $(\mu \mathrm{m})$} & 35 & 55 & 44.8 & 5.8 & 12.9 & 25 \\
\hline & 27 & 50 & 38.7 & 6.5 & 16.7 & 16 \\
\hline \multirow[t]{2}{*}{ Length of buccal field $(\mu \mathrm{m})$} & 28 & 45 & 36.7 & 5.2 & 14.2 & 25 \\
\hline & 29 & 53 & 41.4 & 6.7 & 16.1 & 16 \\
\hline \multirow[t]{2}{*}{ Membranelles $(n)$} & 22 & 25 & 23.4 & 0.9 & 3.9 & 25 \\
\hline & 22 & 27 & 24.8 & 1.6 & 6.5 & 11 \\
\hline \multirow[t]{2}{*}{ Total cirral rows $(n)$} & 11 & 11 & 11 & $\mathbf{0}$ & $\mathbf{0}$ & 25 \\
\hline & 9 & 12 & 10.3 & 1.0 & 9.2 & 7 \\
\hline \multirow[t]{2}{*}{ TC in 2 nd row $(n)^{*}$} & 2 & 3 & 2.2 & 0.4 & 18.8 & 24 \\
\hline & - & - & - & - & - & - \\
\hline \multirow[t]{2}{*}{ TC in 3 rd row $(n)^{*}$} & 2 & 5 & 3.9 & 0.9 & 23.7 & 24 \\
\hline & - & - & - & - & - & - \\
\hline \multirow[t]{2}{*}{ Dorsal kineties $(n)$} & 7 & 8 & 7.3 & 0.5 & 6.3 & 25 \\
\hline & 7 & 9 & 7.8 & 0.8 & 7.0 & 6 \\
\hline \multirow[t]{2}{*}{ Cirri in migratory row $(n)$} & 6 & 8 & 7.0 & 0.7 & 10.4 & 25 \\
\hline & 6 & 9 & 7.9 & 0.9 & 11.8 & 9 \\
\hline \multirow[t]{2}{*}{ Macronuclei $(n)$} & 1 & 1 & 1 & 0 & 0 & 25 \\
\hline & 1 & 1 & 1 & 0 & 0 & 16 \\
\hline \multirow[t]{2}{*}{ Length of macronucleus $(\mu \mathrm{m})$} & 13 & 30 & 21.0 & 4.5 & 21.3 & 25 \\
\hline & 15 & 23 & 18.6 & 2.5 & 13.3 & 13 \\
\hline \multirow[t]{2}{*}{ Width of macronucleus $(\mu \mathrm{m})$} & 11 & 28 & 18.2 & 3.8 & 20.9 & 25 \\
\hline & 14 & 21 & 16.9 & 2.1 & 12.4 & 13 \\
\hline
\end{tabular}

${ }^{*}$ Numbered from left to right on ventral side.

In 1994, G. Fryd-Versavel (in Tuffrau \& Fleury, 1994) reported a form under the name C. convexa Kahl, 1932, for which she failed, however, to supply some important morphological features, e.g. the size, the cortical granules and the dorsal structure (Fig. 5b, c). Differences between this isolate and the present form exist only in the small number of TC (about three rather than four to eight in the Chinese population) and possibly fewer membranelles (about 15 as depicted compared with 22-25). Such differences, however, are highly likely to be population-dependent. Consequently, we assume that these two types are conspecific.

A morphogenetic stage was also documented by G. FrydVersavel (in Tuffrau \& Fleury, 1994) as well, which exhibits that a short row was formed at the posterior end of one cirral anlage (arrow in Fig. 5c). A similar structure was also observed in the related taxon, K. marina, in which the migratory row generates from a single cirral primordium and then shifts to the post-oral position in the final division phase (C. Shao, W. Song, A. Warren, K. A. AlRasheid, X. Hu and $\mathrm{H}$. Ma, unpublished). Hence, this structure is probably misinterpreted as a transverse row because the 'true' TC are formed from the posterior ends of several rightmost frontoventral-transverse (FVT)-cirral anlagen. Considering this understanding, this structure is defined as a migratory row.

In the original description of C. convexa, the migratory row was defined as TC while the true TC were not mentioned (Kahl, 1932). This could be due to a misinterpretation: the bases of the TC are only slightly larger than those of other cirri and the cirral length is about the same. It is reasonable to believe that these TC were overlooked as observed in vivo.

\section{Phylogenetic position of Caryotricha and taxonomy of spirotrichs}

In the widely accepted system of Lynn \& Small (2002), the class Spirotrichea includes seven subclasses: Protocruziidia, Licnophoridia, Phacodiniidia, Stichotrichia, Hypotrichia/ euplotids, Oligotrichia and Choreotrichia. The kiitrichids are assigned as an order (Kiitrichida) within the subclass Hypotrichia, as relatives of the well-described euplotids. Based on SSU rRNA gene and alpha-tubulin gene sequence analyses as well as the morphogenesis information for $K$. marina, Li et al. (2009) nevertheless suggest in an accompanying paper the elevation of the kiitrichids to subclass rank, i.e. a new subclass Protohypotrichia Shi et al., 


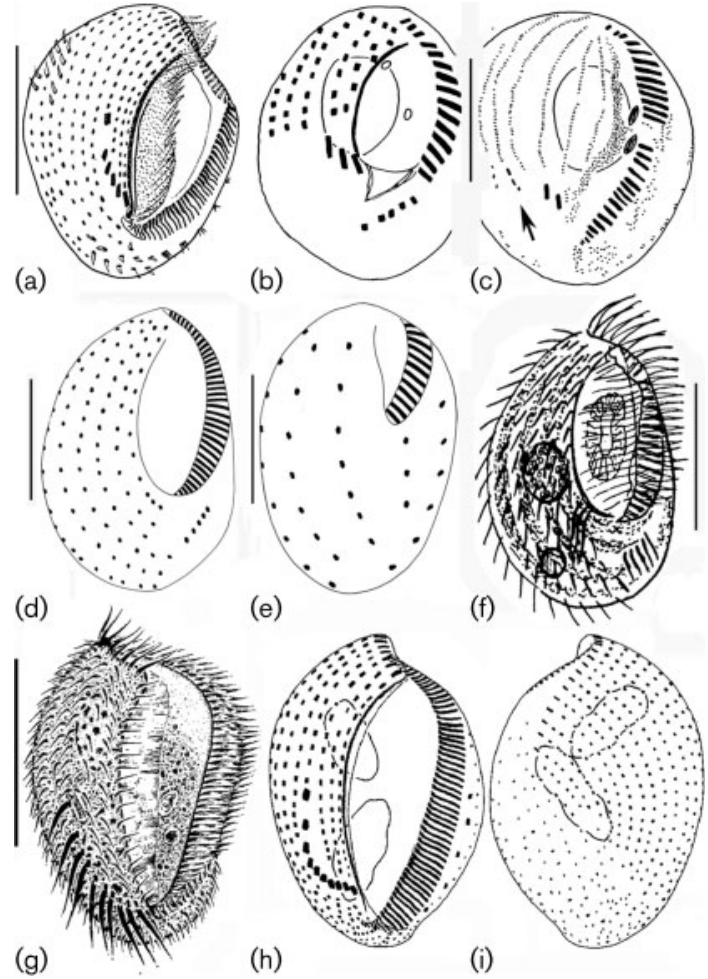

Fig. 5. Comparative illustrations of other populations and some closely related species. (a, g-i) K. marina, after Fleury et al. (1986) (a) and from Song \& Wilbert (1997) $(\mathrm{g}-\mathrm{i}) .(\mathrm{d}, \mathrm{f}) \mathrm{C}$. convexa, after Borror (1972) (d) and Kahl (1932) (f). (b, c) C. minuta (called C. convexa), from Fryd-Versavel in Tuffrau \& Fleury (1994); a divider in middle morphogenetic stage is shown in (c). (e) Psilotricha viridis, after Borror (1972). Bars, $70 \mu \mathrm{m}(\mathrm{a}, \mathrm{g}), 30 \mu \mathrm{m}(\mathrm{b}-\mathrm{d}, \mathrm{f})$ and $20 \mu \mathrm{m}(\mathrm{e})$.

2009. As revealed in the present work, the CaryotrichaKiitricha clade branches between the Phacodiniidia (Phacodinium) and Licnophoridia (Licnophora), thus as an outgroup or peripheral clade to the euplotids or hypotrichs. Neither the current molecular data nor the morphology/morphogenesis suggest that the CaryotrichaKiitricha group is closely related to the euplotids or affiliated with the Hypotrichia (sensu Lynn \& Small, 2002). The evidence derived from the phylogenetic analysis of the C. minuta SSU rRNA gene sequence confirms an assumption of Li et al. (2009): kiitrichids do not appear as a member of the subclass Hypotrichia (sensu Lynn \& Small, 2002), but rather represent an independent clade at the same taxonomic level within the Spirotrichea. Moreover, given the distinctly primitive ciliature (i.e. cirri on the ventral side generally uniform, no clearly defined marginal cirral rows, ciliature on the dorsal side mixed with cirri and dikinetids, no clearly differentiated dorsal kineties; Song \& Wilbert, 1997; Lynn \& Small, 2002; Li et al., 2009), the genus Caryotricha, as well as Kiitricha, might represent an ancestral type within the spirotrichs.
PP from BI and bootstrap values from NJ, LS and MP analyses based on the SSU rRNA gene sequence strongly support the spirotrich ciliates as a monophyletic assemblage except the subclass Licnophoridia, which clusters as sister to Armophorea and Litostomatea. This suggests that the systematic position of the licnophorids within the spirotrichs might have been misinterpreted. However, we cannot exclude that this may also be an artificial result of undersampling (low taxon sampling). Obviously, more sequence data and additional gene sequences are necessary to reconsider the true phylogenetic position of the licnophorids. The results described in this paper also illustrate the difficulties of determining which morphological features more reliably indicate the fundamental schisms in ciliate evolution or which organisms are primitive. This is especially true when ontogenetic data are unavailable. Once more, it becomes obvious that the phylogeny of the ciliated protozoa will clearly benefit from more detailed 'traditional' information (e.g. morphogenesis) combined with a wealth of additional sequence data.

\section{ACKNOWLEDGEMENTS}

This work was supported by the National Science Foundation of China (number 30670280) and by the Deutsche Forschungsgemeinschaft (DFG, STO 414/2-3).

\section{REFERENCES}

Bernhard, D., Leipe, D. D., Sogin, M. L. \& Schlegel, K. M. (1995). Phylogenetic relationships of the Nassulida within the phylum Ciliophora inferred from the complete small subunit rRNA gene sequences of Furgasonia blochmanni, Obertrummia georgiana, and Pseudomicrothorax dubius. J Eukaryot Microbiol 42, 126-131.

Borror, A. C. (1972). Revision of the order Hypotrichida (Ciliophora, Protozoa). J Protozool 19, 1-23.

Carey, P. G. (1992). Marine Interstitial Ciliates. An Illustrated Key. London: Chapman \& Hall.

Chen, Z. \& Song, W. (2001). Phylogenetic positions of Uronychia transfuga and Diophrys appendiculata (Euplotida, Hypotrichia, Ciliophora) within hypotrichous ciliates inferred from small subunit ribosomal RNA gene sequences. Eur J Protistol 37, 291-301.

Corliss, J. O. (1979). The Ciliated Protozoa: Characterization, Classification and Guide to the Literature, 2nd edn. Oxford: Pergamon.

De Puytorac, P., Grain, J. \& Legendre, P. (1994). An attempt at reconstructing a phylogenetic tree of the Ciliophora using parsimony methods. Eur J Protistol 30, 1-17.

Elwood, H. J., Olsen, G. J. \& Sogin, M. L. (1985). The small subunit ribosomal RNA gene sequences from the hypotrichous ciliates Oxytricha nova and Stylonychia pustulata. Mol Biol Evol 2, 399-410.

Felsenstein, J. (2006). PHYLIP (phylogeny inference package) version 3.66. Distributed by the author. Department of Genome Sciences, University of Washington, Seattle, USA.

Fitch, W. M. \& Margoliash, E. (1967). Construction of phylogenetic trees. Science 155, 279-284.

Fleury, A., Iftode, F., Deroux, G. \& Fryd-Versavel, G. (1986). Unité et diversité chez les hypotriches (protozoaires ciliés). III. Éléments d'ultrastructure comparée chez divers représentants du sous-ordre des 
Pseudohypotrichina et remarques générales. Protistologica 22, 65-87 (in French).

Gerassimova, Z. P. \& Seravin, L. N. (1976). Ectoplasmic fibrillar system of Infusoria and its role for the understanding of their phylogeny. Zool Zh 55, 645-656.

Hall, T. A. (1999). BioEdit: a user-friendly biological sequence alignment editor and analysis program for Windows 95/98/NT. Nucleic Acids Symp Ser 41, 95-98.

Hammerschmidt, B., Schlegel, M., Lynn, D. H., Leipe, D. D., Sogin, M. L. \& Raikov, I. B. (1996). Insights into the evolution of nuclear dualism in the ciliates revealed by phylogenetic analysis of rRNA sequences. J Eukaryot Microbiol 43, 225-230.

Huelsenbeck, J. P., Ronquist, F., Nielsen, R. \& Bollback, J. P. (2001). Bayesian inference of phylogeny and its impact on evolutionary biology. Science 294, 2310-2314.

Kahl, A. (1932). Urtiere oder Protozoa. I. Wimpertiere oder Ciliata (Infusoria). 3. Spirotricha. Tierwelt Dtl 25, 399-650 (in German).

Kimura, M. (1980). A simple method for estimating evolutionary rates of base substitutions through comparative studies of nucleotide sequences. J Mol Evol 16, 111-120.

Li, L., Shao, C., Song, W., Lynn, D. H. \& Chen, Z. (2009). Does Kiitricha (Protista, Ciliophora, Spirotrichea) belong to Euplotida or represent a primordial spirotrichous taxon? With suggestion to establish a new subclass Protohypotrichia. Int J Syst Evol Microbiol 59, 439-446.

Lynn, D. H. (1996). Systematics of ciliates. In Ciliates: Cells as Organisms, pp. 51-72. Edited by K. Hausmann \& P. C. Bradbury. Stuttgart: Gustav Fischer.

Lynn, D. H. \& Small, E. B. (2002). Phylum Ciliophora Doflein, 1901. In An Illustrated Guide to the Protozoa, 2nd edn, pp. 371-656. Edited by J. J. Lee, G. F. Leedale \& P. C. Bradbury. Lawrence, KS: Society of Protozoologists.

Lynn, D. H. \& Strüder-Kypke, M. (2002). Phylogenetic position of Licnophora, Lechriopyla, and Schizocaryum, three unusual ciliates (phylum Ciliophora) endosymbiotic in echinoderms (phylum Echinodermata). J Eukaryot Microbiol 49, 460-468.

Medlin, L., Elwood, H. L., Stickel, S. \& Sogin, M. L. (1988). The characterization of enzymatically amplified eukaryotic 16S-like rRNA-coding regions. Gene 71, 491-499.

Miao, M., Song, W., Chen, Z., Al-Rasheid, K. A. S., Shao, C., Jiang, J. \& Guo, W. (2007). A unique euplotid ciliate, Gastrocirrhus (Protozoa,
Ciliophora): assessment of its phylogenetic position inferred from the small subunit rRNA gene sequence. J Eukaryot Microbiol 54, 371-378.

Nylander, J. A. A. (2004). MrModeltest version 2. Distributed by the author. Department of Systematic Zoology, Evolutionary Biology Centre, Uppsala University, Sweden.

Saitou, N. \& Nei, M. (1987). The neighbor-joining method: a new method for reconstructing phylogenetic trees. Mol Biol Evol 4, 406-425.

Shi, X. L., Song, W. \& Shi, X. B. (1999). Systematic revision of the hypotrichous ciliates. In Progress in Protozoology, pp. 77-154. Edited by W. Song, X. L. Shi, X. Hu, Y. Lei, J. Wei, Z. Chen, X. B. Shi \& M. Wang. Qingdao: Ocean University Press (in Chinese).

Shin, M. K., Hwang, U. W., Kim, W., Wright, A.-D. G., Krawczyk, C. \& Lynn, D. H. (2000). Phylogenetic position of the ciliates Phacodinium (order Phacodiniida) and Protocruzia (subclass Protocruziidia) and systematics of the spirotrich ciliates examined by small subunit ribosomal RNA sequences. Eur J Protistol 36, 293-302.

Small, E. B. \& Lynn, D. H. (1981). A new macrosystem for the phylum Ciliophora Doflein, 1901. Biosystems 14, 387-401.

Small, E. B. \& Lynn, D. H. (1985). Phylum Ciliophora. In An Illustrated Guide to the Protozoa, pp. 393-575. Edited by J. J. Lee, S. H. Hutner \& E. C. Bovee. Lawrence, KS: Society of Protozoologists.

Song, W. \& Wilbert, N. (1997). Morphological studies on some free living ciliates from marine biotopes in Qingdao, China, with descriptions of three new species: Holosticha warreni nov. spec., Tachysoma ovata nov. spec. and T. dragescoi nov. spec. Eur J Protistol 33, 48-62.

Swofford, D. L. (2002). PAUP: phylogenetic analysis using parsimony. Sunderland, MA: Sinauer.

Thompson, J. D., Higgins, D. G. \& Gibson, T. J. (1994). CLUSTAL W: improving the sensitivity of progressive multiple sequence alignment through sequence weighting, position-specific gap penalties and weight matrix choice. Nucleic Acids Res 22, 4673-4680.

Tuffrau, M. \& Fleury, A. (1994). Classe des Hypotrichea Stein, 1859. In Traité de Zoologie, Tome II, Infusoires Ciliés, Fasc. 2, Systématoque, pp. 83-151. Edited by P. de Puytorac. Masson: Paris (in French).

Wilbert, N. (1975). Eine verbesserte Technik der Protargolimprägnation für Ciliaten. Mikrokosmos 64, 171-179 (in German).

Xu, K., Lei, Y. \& Choi, J. K. (2008). Kiitricha minuta n. sp., a peculiar hypotrichous ciliate (Ciliophora, Spirotrichea) from the Yellow Sea. J Eukaryot Microbiol 55, 201-206. 